\title{
Teaching
Methods
}

\section{Comparing Conventional, Hybrid, and Distance Learning Courses in Horticulture}

\author{
William J. Sciarappa ${ }^{1,4}$, Vivian Quinn ${ }^{2}$, and Daniel L. Ward ${ }^{3}$
}

AdDitional InDEx wORDs. horticultural education, online learning, e-College, teaching methods, student assessment, hybrid courses, computer-assisted instruction, web-based pedagogy, distance education

SUMMARY. In a conventional sophomore level course entitled "Organic Farming and Gardening," 114 undergraduate students registered from years 2007 to 2009. Due to high demand and insufficient classroom space, this conventional curriculum was reformatted with identical course content into both a hybrid and a fully online version in which 361 students registered from years 2010 to 2012 and 336 students from 2013 to 2015 . In comparing conventional instruction with hybrid and fully online versions over a 9-year period, few significant differences were found in final grades involving 811 students. Final class grade averages of these three learning systems ranged from $85.5 \%$ to $89.6 \%$ over their first 3-year spans. Over their 6-year span, the conventional class average of $\mathbf{8 9 . 6 \%}$ was higher compared with $\mathbf{8 8 . 3 \%}$ for the hybrid format and $\mathbf{8 6 . 8 \%}$ for the online format. Student evaluation surveys assessed faculty performance with eight evaluative questions on a 1 to 5 scale from years 2012 to 2014 . No significant difference existed between teaching in person vs. remotely, averaging 4.35 for the hybrid and 4.17 for the online. An additional eight questions measured educational methodology, technology, student confidence, and class satisfaction. There were no significant differences in comparing the combined averages of 4.12 for the hybrid format and 4.00 for the online version. Student responses indicated a significant preference overall for hybrid and online course formats compared with conventional methods. Registration numbers indicated an overwhelming choice for online education with an average class enrollment of 91.0 students compared with 38.0 students for conventional classes and 25.2 students for the hybrid format.

A $\mathrm{n}$ important institutional issue at many large public and private universities is lack of classroom space due to the greatly increased student enrollment over

${ }^{1}$ Agriculture and Resource Management Agents, Rutgers, The State University, P.O. Box 5033, 4000 Kozloski Road, Freehold, NJ 07728

${ }^{2}$ Rutgers Cooperative Extension Monmouth County, P.O. Box 5033, 4000 Kozloski Road, Freehold, NJ 07728

${ }^{3}$ Department of Plant Biology and Pathology, Rutgers University, Rutgers Agricultural Research and Extension Center, 121 Northville Road, Bridgeton, NJ 08302

${ }^{4}$ Corresponding author. E-mail: sciarappa@njaes. rutgers.edu.

doi: 10.21273/HORTTECH03377-16 design as course schedule, syllabi, objectives, test results, grading criteria, assignments, projects, and links. Paparozzi and Williams (2000) emphasized online participation and openended questions. Lineberger (2001) discussed the transition from webassisted to web-based learning. Such early literature set the stage for building better e-learning systems in higher education. Educators now need to incorporate multimedia and transition from text-lecture methods to design more effective curriculum (Brown, 2001).

Dey et al. (2009) reported video modules to be better than actual live classroom situations in knowledge transfer as students responded more positively to personalized video presentations. Some studies have documented significant educational advantages to online instruction. Zhang (2005) found multimedia methods superior to conventional lecture/text presentation in online learning and knowledge gain. Computer instruction using photographs on the web was found superior to live laboratories in plant identification at Texas Tech University (Seiler et al., 2002) and at the University of Minnesota (Anderson and Walker, 2003).

In a case study, comparing conventional classroom instruction vs. distance learning for fruit crops at the University of Georgia, online students had higher test scores on chapter evaluations, final exams, and overall course grades in all 3 years Rieger (2002). Teolis et al. (2007) found that, academic student performance is a bottom-line parameter in comparing formats. Similarly, Hay et al. (2008) and Lippert et al. (2000) measured pre- and postcourse learning and found it to be the best indicator of teaching quality through online technology. In assessing online courses in the United States, Milliron (2010) targeted clear educational objectives and course structure as essential to self-paced, distance learning. Evaluating knowledge gain, student satisfaction, and confidence among academic formats are key parameters in documenting educational impact and providing baseline information for course improvement (Henss et al., 2006; Shoemaker, 2010; VanDerZanden et al., 2008).

\section{Overview}

Current challenges with distance education are to create courses in a minimum amount of time, expense, 
and technical skill, yet produce an educationally sound and effective curriculum. To be successful, such efforts must maintain educational relevance, reach new audiences, and expand the educational market segment (Parker, 2009). This 10 -year case study focuses on an agricultural-horticultural course entitled "Organic Farming and Gardening" that piloted as a one-credit version in year 2006. An expanded two-credit version continued from 2007 to 2009 as conventional classes for undergraduate students in the curricula of the Rutgers School of Environmental and Biological Sciences. Students were a typical diversity of undergraduates in science-elective classes of sophomores to seniors which included both science and nonscience majors. The conventional course evolved into a web-assisted version in 2008 and 2009; 75\% in person and $25 \%$ online. Live classroom PowerPoint (Microsoft, Redmond, WA) presentations were video-captured, edited, and supplemented to be used in future online presentations as enriched educational modules. Year 2010 marked the first web-based hybrid (50\% in person and $50 \%$ online) and totally online format $(100 \%$ online). To accommodate more learners in the same amount of time, the conventional approach was discontinued while both the hybrid and online versions were taught concurrently. McKenney et al. (2010) compared three instructional methods and their time investment. Similarly, our study situation provided a basis for comparison of methodologies in regards to instructor performance, student learning outcomes, and other parameters.

\section{Goals and objectives}

General goals were to learn how to use and incorporate new online technology into both hybrid and fully online formats and compare yearly cohorts of students in differing educational environments. A hybrid version is presented live for one-half of the semester and is web-based for one-half, whereas an online version is totally web based. Both formats had course content and evaluative methods equivalent to the previous conventional version. Educational objectives for the course comparisons of "Organic Farming and Gardening" were to tabulate annual student enrollment and grades for the hybrid and the online class formats vs. the conventional format and to evaluate instructor performance via student feedback. The experimental design analyzed academic grades, measured knowledge gain, evaluated instructor performance, and surveyed student satisfaction. Such comparative information would help examination of instructional effectiveness of a learning management system. The LMS (eCollege; Pearson eCollege, Denver, $\mathrm{CO})$ is part of the Pearson Learning Studio and learning management system that is a comprehensive, ondemand, online learning solution available for the delivery of fully online, hybrid, and face-to-face courses.

\section{Materials and methods}

Course Development. The first Organic Farming and Gardening course in 2006 was only offered as a one-credit conventional class. With no web-assisted or online components, the course consisted of live lecture, reading materials, and standard PowerPoint presentations. Years 2007, 2008, and 2009 transitioned to a two-credit conventional format with laboratory-greenhouse work and some web-assisted resources using an e-Companion shell (a forerunner of eCollege). Class size was 38 students nearing the maximum seating room capacity of 40 desks.

Course construction. Learning methods were modified from the conventional course to include online instruction and technology in organic farming and gardening classes. Basic syllabus objectives offered students an introduction to basic philosophy, agricultural practices, organic cropping methods, and pressing issues. More advanced objectives were to foster independent learning via distance education and web based instruction, encourage creative thinking in agricultural problem solving on the farm or in the garden, and effectively communicate complex concepts with other contemporaries. The course content remained the same for these new hybrid and online versions which derived from the earlier conventional classes. Digital delivery included video modules captured from conventional sessions. These educational modules provided a presenter video lecture, professional profile, key search words, references, related assignments, and follow-up questions to develop richer course content. Specific syllabus topics included the history of organic farming, design of an organic farm or garden, planning an organic operation, crop and seed selection, soil building, fertility, composting, seed starting, specialty crops, plant growth measurements, data collection, pest management, natural landscapes, and rain garden construction.

Course equipment. New computer-driven equipment such as a LMS (e-College) instructional shell, Qumu (Qumu Corp., Minneapolis, MN) video capture system, portable mini-webcams, and digital communications were integrated fully into the online version and partially into the hybrid version, which was not available in the conventional format from years earlier. Live lectures and associated PowerPoint presentations from the conventional and live hybrid presentations were video-captured with the Qumu/C-BOX/Shuttle device. These digital recordings were provided remotely as a dual-framed video view of presenter and PowerPoint provided remotely to the online classes on demand through the Rutgers learning management system, eCollege (Fig. 1). Students were able to remotely change the view size of either frame, advance to different portions of the presentation for review and print out PowerPoint slides.

Course structure. Hybrid and totally online formats were created in eCollege templates for two different sections in a two-credit course titled "Organic Farming and Gardening": course numbers 01527401 and 015 27490.

Hybrid courses had seven live, double-period sessions (2.5 h each) and seven online learning modules, whereas online courses had 21 learning modules online. The two syllabi were based on the previous 3 years of conventional methodology and were constructed equally as to course content and expected time commitments. These online syllabi provided a video greeting by the primary instructor, a course introduction, an overview, learning objectives, project tasks, exam schedule, assessment measures, and video recorded presentations from previous conventional sessions. Course work load, assignments, evaluation rubrics, and grading categories were equally balanced 


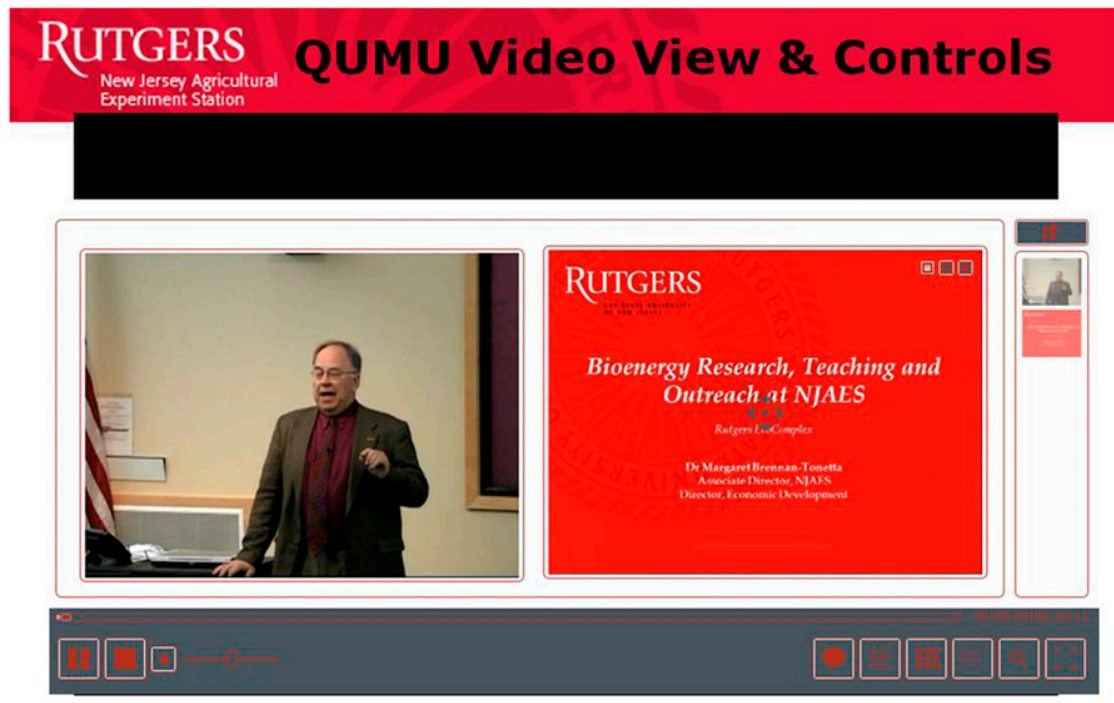

Fig. 1. Student view of video lesson and Qumu (Qumu Corp., Minneapolis, MN) control in eCollege learning management system (Pearson eCollege, Denver, CO) with dual-framed view of presenter and PowerPoint (Microsoft, Redmond, WA) to the online classes on demand.

for both formats. Educational content was divided into study modules such as soil testing, soil building, composting, horticultural concepts, agricultural methods, crop selection, sustainability, and integrated pest management. Website links were vetted and used as either basic or supplemental material in lieu of formal textbooks. Selected videos, readings, and books in horticulture were offered as choices in class assignments.

Independent experiential learning via travel to farm, garden, and greenhouse sites as well as communitysupported agriculture operations was offered to all classes equally. Online students were allowed to work handson with teams of hybrid students in independent greenhouse projects that compared the effect of five organic fertilizers on growth of the Rutgers tomato cultivar as well as ethnic specialty vegetables. Similarly, extra credit was given for volunteers working on the university organic farm who provided a final PowerPoint report. Student visits were verified by digital still photos and videos embedded into individual PowerPoint presentations that were time coded, narrated by students or noted in their slides.

InSTRUCTIONAL TOOLS. The online system has digital features including chat rooms, webinars, grading analysis, educator/student gradebooks, and remote teaching evaluations. Test bank questions for remote assessment featured question randomization. Essays were submitted online and graded with rubrics by the educational technologist. The hybrid classes had direct instruction, live group discussion and question-and-answer segments with audience response devices (Sciarappa and Quinn, 2014). The online classes were able to view similar videotaped sessions, e-mail questions, join in a digital chat room or remotely participate in video webinars and podcasts streamed and "recorded live" online or stored for later review.

Educational evaluation. Student numbers and test performance were compiled over a 9-year period in three different formats of "Organic Farming and Gardening"; conventional, hybrid, and online. Pre- and postinstruction questions were used in assessing knowledge gains either before semester instruction or before class instruction in the hybrid vs. online comparison. Final grades were automatically calculated by the eCollege program (Table 1 ) and analyzed using analysis of variance (ANOVA). The MIXED procedure of SAS (version 9.4; SAS Institute, Cary, NC) was used to perform a two-way ANOVA testing for main effects of year and class format as well as their interaction. The significant interaction of year and class format was further analyzed using tests of simple main effect comparing class formats within each year. The MIXED procedure was also used to fit a two-way ANOVA that controlled for yearly effects to compare class formats for both student instructional ratings of instructor performance and their impressions of the course structure.

Grade components across class types over 3-year spans included written report grades, individual projects, extra credit, open-ended questions, chat rooms, and measures of in-class or online participation via website use in each class module. A formula for assessing online participation was developed: time $\times$ frequency $\times$ quality $=$ numerical grade. Time online was recorded by the eCollege system in number of minutes and multiplied by number of separate responses. These responses were qualified on 0.1 to 1.0 graduated scale with 0.5 rated fair, 0.75 good and 1.0 being excellent. Participation online counted for $30 \%$ of the online class grade and for $15 \%$ of the hybrid class grade that also allowed $15 \%$ credit for in-class participation.

\section{Results}

Class registration. Annual class sizes of the web-assisted, conventional e-Companion course in years 2007-09 were 31, 39, and 44 students, respectively. Although this evolving, quasi-hybrid/conventional class reduced the classroom space needs by $25 \%$ per semester, many other potential students were still denied registration due to lack of weekly classroom space. By offering both a web-based hybrid and a totally online alternative in 2010 through 2015 , we were able to accommodate over 100 students annually in these distance education formats. In the first year of concurrent class formats, the 2010 registration was 32 students in the web-based hybrid and 69 students in the web-based online version; a combined 102 students enrolled compared with a combined 114 students from the previous 3 years (2007-09) of the former conventional version (Table 2 ).

Over the course of this 9-year study, 814 undergraduates were taught with average class sizes of 38 students for the conventional, 25 students for the hybrid, and $91 \mathrm{stu}-$ dents for the online. Student preference as determined by enrollment numbers was 3.64 times greater for the online vs. the hybrid format. In 
Table 1. Gradebook categories and eCollege (Pearson eCollege, Denver, CO) calculations. Eight grading categories are automatically calculated with individual weighting per category allowing students to remotely view their current status or final grade percentage.

\begin{tabular}{|c|c|c|c|c|c|c|c|c|c|}
\hline Student & $\begin{array}{c}\text { Current } \\
\text { events (\%) }\end{array}$ & $\begin{array}{c}\text { Organic } \\
\text { design (\%) }\end{array}$ & $\begin{array}{c}\text { Exam } \\
\text { one }(\%)\end{array}$ & $\begin{array}{c}\text { Exam } \\
\text { two }(\%)\end{array}$ & $\begin{array}{l}\text { Extra } \\
\text { credit }\end{array}$ & $\begin{array}{c}\text { Final } \\
\text { project }(\%)\end{array}$ & $\begin{array}{c}\text { General } \\
\text { participation (\%) }\end{array}$ & $\begin{array}{c}\text { Trip } \\
\text { report }(\%)\end{array}$ & $\begin{array}{c}\text { Weighted } \\
\operatorname{avg}(\%) \\
\end{array}$ \\
\hline A & 94 & 90 & 92 & 89 & * & 78 & 72 & 92 & 82.9 \\
\hline B & 95 & 95 & 94 & 82 & * & 93 & 72 & 92 & 85.9 \\
\hline $\mathrm{D}$ & 86 & 94 & 93 & 88 & * & 95 & 70 & 95 & 85.6 \\
\hline $\mathrm{E}$ & 94 & 95 & 83 & 79 & * & 94 & 92 & 94 & 90.9 \\
\hline $\mathrm{H}$ & 95 & 94 & 96 & 83 & * & 98 & 96 & 94 & 94.6 \\
\hline
\end{tabular}

*Completed an additional assignment.

Table 2. Student enrollment $(\mathrm{N}=814)$ and grade comparison in the sophomorelevel class "Organic Farming and Gardening" at Rutgers University by year and class format.

\begin{tabular}{llccr}
\hline Yr & Class format & $\begin{array}{c}\text { Students } \\
\text { enrolled (no.) }\end{array}$ & Mean grade (\%) & SD (\%) \\
\hline 2007 & Conventional & 31 & 91.0 & 5.9 \\
2008 & Conventional & 39 & 93.4 & 2.8 \\
2009 & Conventional & 44 & 88.2 & 10.6 \\
2010 & Hybrid & 32 & $90.6 \mathrm{a}^{\mathrm{z}}$ & 4.3 \\
& Online & 69 & $84.0 \mathrm{a}$ & 13.0 \\
2011 & Hybrid & 27 & $82.0 \mathrm{a}$ & 14.4 \\
& Online & 103 & $89.3 \mathrm{~b}$ & 9.0 \\
2012 & Hybrid & 35 & $86.6 \mathrm{a}$ & 11.5 \\
& Online & 98 & $86.4 \mathrm{a}$ & 10.7 \\
2013 & Hybrid & 24 & $88.5 \mathrm{a}$ & 7.6 \\
& Online & 101 & $85.5 \mathrm{a}$ & 11.4 \\
2014 & Hybrid & 17 & $89.7 \mathrm{a}$ & 12.9 \\
& Online & 77 & $84.9 \mathrm{a}$ & 11.2 \\
2015 & Hybrid & 16 & $89.3 \mathrm{a}$ & 8.2 \\
& Online & 101 & $88.1 \mathrm{a}$ & 12.3 \\
\hline
\end{tabular}

${ }^{\mathrm{z}}$ Mean grades within a year with different accompanying letters are significantly different at $\alpha=0.05$ by analysis of variance.

2011 and 2012, online class numbers continued to increase up to 103 and 98 students, respectively. Online registration was capped around 100 due to limits on our educational technology staff to communicate with students, assist with technical problems, assess reports, and grade tests. The total combined class numbers for the online and hybrid formats from 2010 to 2012 was 101,130 , and 133 students, respectively - an average of 123 students per year. This increase via e-learning from 2010 to 2012 was 3.2 times greater than the conventional average of 38 students from 2007 to 2009 . From 2013 to 2015 , the annual numbers of registered students in just the online format was 101, 77, and 101 students, respectively, averaging 93.0 students per year. This online total of 279 students online was 2.9 times the original conventional cohorts and 4.9 times greater than the 57 students in the hybrid classes of the same 3-year span (Table 2). Students clearly continued to place their tuition dollars in registering for the online format vs. the conventional or the hybrid forms.

Precourse testing. Precourse testing results of both 2011 and 2012 classes showed the hybrid class means of correct answers from selected questions were $51.7 \%$ compared with $48.6 \%$ for the online class with a standard deviation of $11.4 \%$. These results indicated classes began with relatively the same level of baseline knowledge before starting the course instruction.

Pre-post Quizzes. Significant learning was measured throughout the 2010 semester from both classes. Initial preinstruction grades of $56.3 \%$ and $59.2 \%$ for the hybrid class vs.
$58.7 \%$ and $54.1 \%$ for the online (58.5\% combined average) were raised to a post-test average of $89.2 \%$ and $85.8 \%$ and $80.3 \%$, and $77.9 \%$ ( $83.3 \%$ combined average), respectively. There was no significant difference between the formats. This increase of knowledge ranging from $25 \%$ to $30 \%$ reflects the amount of knowledge gained from these distance education formats. Similar results were found in the following years for both classes.

EXAM Grades. The 2010 exam grades on two major tests in the first comparative year for the hybrid course averaged $92.4 \%$ and $81.3 \%$ compared with online courses that were $85.3 \%$ and $80.0 \%$. With individual standard deviations ranging from $7.25 \%$ to $9.74 \%$, these small differences were not individually significant, but the trend in the first exam was toward higher grades in the hybrid format. This difference and variability was primarily attributed to initial online inexperience without in-class instruction for online test taking. In 2011-12, these problems were resolved with better online instructions. Exam grade differences were then less variable. With more experienced online users by years 2012-15, the online exam grade averages were equivalent to the hybrid version.

Final grades. In combining final grades in 3-year spans, conventional courses from 2007 to 2009 , hybrid from 2010 to 2012 , and 2013 to 2015 , online from 2010 to 2012 and 2013 to 2015 averaged $89.6 \%$, $85.5 \%, 89.1 \%, 87.3 \%$, and $86.2 \%$, respectively, all within a small range of $4.1 \%$. In comparing the 6 years of concurrent hybrid and online formats, 
there was only one significant difference with the final grade average in annual replicates. Online class grades were higher than the hybrid classes only in year $2011 \times 7.3$ grade points. Both classes had nonsignificant differences in all other years for final grades (Table 2).

COURSe eVAluUtion COMPARISONS. The Rutgers instructional evaluation form is assessed by students and was analyzed to compare course evaluations from 2012, 2013, and 2014 on a 1 to 5 scale, with 5 being strongly agree. Summarized data of instructor performance for eight educational quality questions from the hybrid format averaged 4.35 , which were not significantly different from the online formats which averaged 4.17 (Table $3)$. These instructor performance ratings met or exceeded the average faculty ratings, which can be described as very good to excellent.

In comparing these two class formats, there was little variance among the student course responses to another set of eight questions of student impressions and personal satisfaction (Table 3 ). Ratings from hybrid classes in 2012, 2013, and 2014 averaged 4.12 with a range between 3.82 and 4.35 . Online average for the same 3 -year period was 4.00 ranging from 3.81 to 4.14 , respectively (Table $3)$. These responses can be described as ranging from good to very good to excellent by the students. The lower scores were in the categories for having "prior interest" and "technical support." In two separate survey questions, they strongly preferred either distance format by a majority of over $90 \%$ compared with similar conventional classes taken previously.

STUDENT CONFIDENCE. Similar to Shoemaker (2010), an assessment of learning was evaluated by student surveys as to their level of confidence and their perceived amount of knowledge gain. The large majority of students in both the online and hybrid formats reported these two parameters as highly increased every year from 2010 to 2015. They also commented that their individual grades would have been similar in a conventional class. Their confidence and knowledge gain were born out quantitatively by their empirical grades of high quality in independent assignments.

\section{Comments and conclusions}

This course curriculum of Organic Farming and Gardening fulfills the requirements for elective science credit for science majors as well as nonscience majors. In logistical comparisons with identical curricular content and test questions, both the hybrid and totally online course formats were found to be improved approaches over a conventional format in terms of class numbers, scheduling, student satisfaction, time-shifting flexibility, travel time savings, and efficient use of university classroom facilities. All the primary content from the conventional course flexibly fit into online versions using text, references, and educational video modules. Final grades from online formats from 2013 to 2015 were as good as the hybrid. Benefits measured or comments reported include significant knowledge gains, student confidence, a live "feel" online, engaging projects and 24-7 contact via e-mail, cell phone and Internet chat groups.

In the first 3-year span from 2010 to 2012 student responses of educational quality found the hybrid was preferred for technical reasons over fully online classes by a small margin, but selection of the online version was much higher and was clearly the favored format. The entire 6-year span showed that despite some drawbacks of distance learning; a total online format was overall as good educationally as a hybrid version and both distance methods were highly preferred over conventional format. We agree with Milliron (2010) that it is time to "end the family feud" between online and conventional educators. Both formats can exist concurrently and effectively extend the educational reach in academic and applied institutions.

Faculty and administrators may also prefer the totally online system in recycling quality presentations digitally, saving travel time, reducing transport expenses, minimizing classroom space, and increasing tuition dollars. Distance education allows registration of university students from remote sites and an extension of the academic calendar with holiday breaks and summer classes. Students were freed up to independently arrange their own

Table 3. Mean student instructional ratings for the sophomore-level class "Organic Farming and Gardening" averaged over the years 2012, 2013, and 2014 at Rutgers University by class format.

\begin{tabular}{|c|c|c|c|c|c|c|c|c|}
\hline \multirow[b]{2}{*}{$\begin{array}{l}\text { Class } \\
\text { format }\end{array}$} & \multicolumn{8}{|c|}{ Instructor and class ratings $(1-5 \text { scale })^{\mathrm{z}}$} \\
\hline & $\begin{array}{l}\text { Instructor } \\
\text { prepared } \\
\text { and } \\
\text { organized }\end{array}$ & $\begin{array}{l}\text { Effective } \\
\text { response }\end{array}$ & $\begin{array}{c}\text { Generated } \\
\text { interest }\end{array}$ & $\begin{array}{c}\text { Positive } \\
\text { attitude and } \\
\text { assistance }\end{array}$ & $\begin{array}{c}\text { Instructional } \\
\text { methods } \\
\text { encouraged } \\
\text { student learning }\end{array}$ & $\begin{array}{c}\text { Teaching } \\
\text { effectiveness }\end{array}$ & $\begin{array}{l}\text { Overall } \\
\text { class } \\
\text { quality }\end{array}$ & $\begin{array}{l}\text { Met objectives } \\
\text { in the syllabus }\end{array}$ \\
\hline Hybrid & 4.38 & 4.32 & 4.32 & 4.36 & 4.30 & 4.50 & 4.34 & 4.54 \\
\hline Online & 4.16 & 4.20 & 4.34 & 4.25 & 4.09 & 4.18 & 4.14 & 4.22 \\
\hline \multirow[t]{2}{*}{$P_{\text {values }}{ }^{\mathrm{y}}$} & 0.585 & 0.799 & 0.976 & 0.783 & 0.535 & 0.310 & 0.488 & 0.393 \\
\hline & $\begin{array}{l}\text { Assigned } \\
\text { grades } \\
\text { fairly }\end{array}$ & $\begin{array}{c}\text { I learned a } \\
\text { great deal }\end{array}$ & $\begin{array}{c}\text { I had a } \\
\text { strong prior } \\
\text { interest }\end{array}$ & $\begin{array}{l}\text { Good balance } \\
\text { readings, } \\
\text { assignments }\end{array}$ & $\begin{array}{l}\text { Comfort using } \\
\text { online system }\end{array}$ & $\begin{array}{l}\text { Technical } \\
\text { support }\end{array}$ & $\begin{array}{c}\text { Online } \\
\text { environment } \\
\text { effectiveness }\end{array}$ & $\begin{array}{l}\text { Recommend } \\
\text { course to others }\end{array}$ \\
\hline Hybrid & 4.20 & 4.07 & 3.87 & 4.29 & 4.07 & 3.82 & 4.35 & 4.30 \\
\hline Online & 4.12 & 4.12 & 3.74 & 4.14 & 3.93 & 3.81 & 4.12 & 4.01 \\
\hline
\end{tabular}

${ }^{\mathrm{z}} 1$ = strongly disagree; 5 = strongly agree.

yProbability values for test of equal mean ratings for class formats within each response by analysis of variance. 
hands-on activities and horticultural experiences in the real world of farming, gardening, and greenhouse production. The online format allows students to more easily increase credit loads while both faculty and students time shift schedules, avoid commuting costs and eliminate travel time.

We conclude that most sophomore to senior students can benefit with a wider choice of both hybrid and totally online classes by integrating online systems, digital devices, and independent study projects stressing student centered, faculty guided instruction. The quantifiable data found in this study supports the quality, effectiveness, and utility of these distance education methods.

\section{Literature cited}

Anderson, N.O. and J.D. Walker. 2003. Effectiveness of web-based versus live plant identification tests. HortTechnology 13:199-205.

Brown, R. 2001. Thinking in multimedia: Research-based tips on designing and using interactive multimedia curricula. J. Ext. 39(3):7 <http://www.joe.org/joe/ 200ljune/ttl.php $>$.

Dey, E., H. Burn, and D. Gerde. 2009. Bringing the classroom to the web: Effects of using new technologies to capture and deliver lectures. Res. Higher Educ. 50:377393.

Hay, D.B., C. Kehoe, M.E. Miquel, S. Hatzipanagos, I.M. Kinchin, S.F. Keevil, and S. Lygo-Baker. 2008. Measuring the quality of e-learning. Brit. J. Educ. Technol. 39:1037-1056.
Henss, S.R., J.M. Zajicek, and R.D. Lineberger. 2006. A comparison of student grades, floral design laboratory skill scores, and course satisfaction of traditional and online sections of a university floral design course. HortTechnology 16:626-632.

Lineberger, R.D. 2001. The transition from web-assisted to web-based teaching: The Hort 315 experience. HortScience 36:524 (Abstr.).

Lippert, R.M., O. Plant, and R. Radhakrishna. 2000. Beyond perception: A pretest and posttest evaluation of a regional internet extension in-service training. J. Ext. 38 (2):7 <http://www.joe.org/joe/ 2000april/a2.php $>$.

McKenney, C.B., E.B. Peffley, and I. Teolis. 2010. Comparison of time investment in common teaching practices among three instructional methods. HortTechnology 20:245-249.

Milliron, M.D. 2010. Online education vs. traditional learning: Time to end the family feud. Chron. High. Educ. 57(11): B30-B32.

Parker, R.T. 2009. Distance education: Taking the first steps. J. Ext. 47(3):7 <http://www.joe.org/joe/2009june/ iw5.php $>$.

Paparozzi, E.T. and K.A. Williams. 2000. Using chat rooms in a plant nutrition course: Bane or boon. HortTechnology 10:280-282.

Paparozzi, E.T., K.A. Williams, R. Geneve, H. Hatterman-Valenti, C. Haynes, H. Krauss, C. McKenney, and J. Pitts. 2011. Development of the AG*IDEA alliance's horticulture graduate certificates program and inter-institutional course share. HortTechnology 21:688-691.
Rieger, M. 2002. Distance education versus classroom instruction in horticulture: An introduction to fruit crops: Case study. HortTechnology 12:513-515.

Sciarappa, W. and V. Quinn. 2014. Integrating digital response systems within a diversity of agricultural audiences. J. Ext. 52(1):7 <http://www.joe.org/joe/ 2014february/a7.php $>$.

Seiler, J.R., O. Popescu, and J.A. Peterson. 2002. A woody plant identification tutorial improves field identification skills. J. Nat. Resour. Life Sci. Educ. 31:12-15.

Shoemaker, C.A. 2010. Student confidence as a measure of learning in an undergraduate principles of horticultural science course. HortTechnolgy 20:683-688.

Sistrunk, L.A. 1998. Using the world wide web for enhancing student learning in future horticultural curricular. HortTechnology 8:29-30.

Stone, A.G., D.D. Treadwell, A.K. Formiga, J.P.G. McQueen, M.M. Wander, J. Riddle, H.M. Darby, and D. Heleba. 2012. eOrganic: The organic agriculture community of practice for eXtension. HortTechnology 22:583-588.

Teolis, I., E.B. Peffley, and D.B. Wester. 2007. Comparing student performance in live versus web-based instruction in herbaceous plant identification. HortTechnology 17:120-124.

VanDerZanden, A.M., D. Sandrock, and D. Kopsell. 2008. Student attitudes and perceptions of an online problem-based learning case study in landscape management. HortTechnology 18:520-523.

Zhang, D. 2005. Interactive multimediabased e-learning: A study of effectiveness. Amer. J. Distance Educ. 19(3):149-162. 